\title{
Survey of the Referral Laboratory Sample Managements of Medical Clinics in Jeju Island
}

\author{
Moo-Sang Chong ${ }^{1 \oplus}$ and Kyutaeg Lee ${ }^{2} \odot$ \\ ${ }^{1}$ Department of Clinical Laboratory Science, Cheju Halla University, Jeju; 2Department of Laboratory Medicine, Green Cross \\ Laboratories, Yongin, Korea
}

\section{Corresponding author:}

Kyutaeg Lee

Department of Laboratory Medicine, Green Cross Laboratories, 107, Ihyeonro 30beon-gil, Giheung-gu, Yongin 16924, Korea

Tel +82-31-260-9077

E-mail kyutaeg@gclabs.co.kr

Received: November 23, 2020

Revised: January 22, 2021

Accepted: January 25, 2021

This is an Open Access article distributed under the terms of the Creative Commons Attribution Non-Commercial License (http://creativecommons.org/licenses/ by-nc/4.0) which permits unrestricted non-commercial use, distribution, and reproduction in any medium, provided the original work is properly cited.
Background: To determine the current status of the referral laboratory sample delivery process, we surveyed the delivery process, such as workers in charge, equipment, sample storage method, and delivery systems of the medical clinics on Jeju Island.

Methods: We collected 142 questionnaires from 300 medical clinics on Jeju Island and analyzed the current status of laboratory samples before delivery to referral laboratory centers.

Results: As $61 \%$ percent of medical clinics did not have a centrifuge, laboratory samples from these clinics were delivered without centrifugation. Most workers in charge of laboratory samples were not trained by specialists regarding proper laboratory sample management. The method of storage in the refrigerator was unacceptable in $13.3 \%$ of medical clinics.

Conclusions: We suggest regular inspection programs for the process of referral laboratory samples and proper training programs for workers in charge of laboratory samples.

(Lab Med Qual Assur 2021;43:94-106)

Key Words Laboratory referral sample management, Medical clinic, Jeju

\section{서론}

현재 우리나라의 의료환경은 의료기술의 발전으로 영상의학검 사와 함께 임상검사에 대한 의존도는 점차 증가하고 있다. 환자의 검체를 다루고 있는 임상검사의 신뢰성 있는 검사결과의 제공은 의료의 질을 결정하는 기본적인 요소이며 임상검사실의 질 관리에 대한 중요성은 이미 국내외적으로 잘 인식되고 있으며, 국내에서 도 이를 법제화하려는 움직임이 있다[1,2].

현재 우리나라 대부분의 종합병원에서는 자체 검사실을 두고 있어 환자 검체의 채혈 후 검사로 이어지는 과정에서 정도관리가 비교적 잘 이루어지고 있다고 추정된다. 그러나 자체 검사실 운영 이 어려운 의원급 의료기관들도 임상 검체의 검사를 많이 이용하 고 있을 뿐만 아니라 대형병원에서도 다양한 희귀질환들을 진단하 기 위한 특수검사를 편리성 및 효용성 면에서 자체 검사실이 아닌 외부 수탁전문 의료기관에 의뢰하게 된다[3]. 각 의료기관에서 외
부 수탁전문 의료기관에 의뢰되는 검체들은 검사 전에 다양한 인 자들에 의하여 영향을 받을 수 있다. 1980 년대 우편을 이용한 검 체 운송방법[4], 시험관 내의 젤의 유무, 미원심분리 검체 혹은 원 심분리 후 검체 운송[5], 계절적 요인들[6]도 검사결과에 영향을 미친다고 보고되었다. 또한 인체에서 채취한 혈액을 포함한 각종 임상 검체들은 시간과 온도에 민감하기 때문에 수송용기, 수송과 정 등 전반적인 모든 면에서 전문적으로 이루어져야 한다[7]. 이와 같이 임상검사의 검체는 검사 전 적절한 관리가 정확한 결과의 도 출에 지대한 영향을 미치나 지금까지의 대부분의 임상 검체의 위 탁에 관한 연구는 채혈 이후부터 검사까지의 관리 및 대책에 대한 연구가 대부분이었다.

육로가 없는 섬이라는 특수성을 가진 제주도에서 운송되는 임 상 검체는 대부분 항공운송을 통하여 수탁검사 의료기관으로 이송 되어 검사가 이루어지고 있는 실정이며, 의원급 의료기관에서 항 공이송 전 검체의 보관시간도 길어질 뿐만 아니라 항공이송 후 수 
탁검사 의료기관으로의 육로 이송에 소요되는 시간이 길어질 수 있어 검체의 보존환경의 변화가 타지방에 비해 빈번할 수 있다. 최 근 태풍, 폭우, 폭설 등에 의해 항공기의 결항과 지연 등으로 검체 수송 및 검체의 보관상 변질 등의 우려가 더욱 가중되고 있다. 특 수한 환경으로 인해 제주도 내 의원급 의료기관에서 채혈 전, 채혈 과정 및 채혈 후 검체의 위탁까지의 검체의 적절한 관리가 검체결 과에 미치는 영향은 타지역보다 더 중요할 수 있다. 이에 본 연구 는 제주도 의원급 의료기관에서의 검체의 전 처리, 종사하는 인력, 장비, 보관방법 등 수탁검사 의료기관으로 위탁 전 과정에서 위탁 검체 관리실태를 설문을 통하여 파악하고자 하였으며 개선방안을 모색하고자 하였다.

\section{재료 및 방법}

제주도 내 진단검사의학과 전문의, 의원급 의료기관에 종사하 는 의료인, 수탁전문 의료기관 제주지역 관리자, 타지역 종합병원 에 근무하는 진단검사의학과 전문의, 수탁전문 의료기관에 근무하 는 진단검사의학과 전문의의 의견을 반영하여 의원급 의료기관 내 에서 시행되는 관리방법과 문제점들에 대해 의견을 수렴하였다. 통합 2주기 의원급 검진기관 평가자료를 참조하여 제주도 의원급 의료기관에서의 검체 관리실태 파악을 위한 설문지를 제작하였다. 조사설문지에는 의원급 의료기관 내에서 실시되는 임상검사에 대 한 기초 조사를 포함하였으며, 위탁검사절차에 대해서는 위탁검 사 담당자, 위탁검사에 대한 지침, 위탁 검체의 채혈자 및 채혈방 법, 검체 용기, 위탁 전 원심분리, 원심분리기의 관리, 냉장보관, 냉 장고의 관리, 위탁 검체 수거방법, 결과만족도 등의 내용으로 설문 지를 제작하였다. 제주도 내 의원급 의료기관 300 개 기관에 설문 지를 배포하였다. 설문지의 회수는 의원급 의료기관에서 설문지와 함께 동봉된 새로운 봉투에 밀봉하여 회수하여 연구자뿐만 아니라 회수자, 의원급 의료기관의 설문지 응답자도 구분할 수 없게 하였 으며, 설문조사 내용은 Appendix 1로 첨부하였다.

\section{결과}

제주도 의원급 의료기관에 보낸 300 개의 설문지 중 142 개 $(47.3 \%)$ 가 회신되었다. 설문지에 회신한 의원급 의료기관 중 의 원급 의료기관 내에서 자체적으로 검사가 이루어지는 검사분야는 임상화학검사가 62 개(43.6\%), 일반혈액검사는 65 개(45.7\%), 일 반면역검사는 57 개( $40.1 \%)$, 요검사는 78 개(54.9\%), 간이혈당검 사는 105 개(73.9\%)의 의원에서 자체 검사를 수행하고 있었다.

\section{1. 제주지역 의원급 의료기관 위탁검사 일반적인 사항}

의원급 의료기관에서 위탁검사 담당자로 지정된 직급은 간호 사, 임상병리사, 간호조무사, 방사선사 순이었으며, 담당자가 여러 직급으로 순환 변경되는 의원은 8 개 의원이었다. 물리치료사, 일 반 사무직원이 위탁검사를 담당하는 의원은 없었다.

대부분의 의원급 의료기관에서 위탁검사지침을 보유하고 있었 으며 지침에 대한 내용을 준수하고 있었다. "위탁검사지침이 있으 며 잘 지키고 있다"고 응답한 58 개 의원 중 위탁검사 담당자가 임 상병리사인 의원은 23 개(39.6\%), 간호사인 의원은 18 개(31.3\%), 간호조무사인 의원은 14 개( $24.1 \%)$, 담당자가 순환 변경되는 의원 은 3 개(0.5\%)의 순이었다. "위탁검사지침이 있으나 잘 지키고 있 지 않다"고 응답한 31 개 의원 중 위탁검사 담당자가 간호사인 의 원은 26 개(83.8\%), 간호조무사인 의원은 4 개(12.9\%), 임상병리 사인 의원은 1 개(0.3\%) 의원 순이었다. "위탁검사지침이 없으나 검체 위탁은 잘 진행되고 있다”고 응답한 51 개 의원 중 위탁검사 담당자가 간호사인 의원은 33 개(64.7\%), 간호조무사인 의원은 8 개(15.6\%), 임상병리사인 의원은 4 개( $7.8 \%)$, 방사선사인 의원은 1 개(1.9\%)의 순이었다. "위탁검사지침이 없으며, 잘 지키고 있지 않다"고 응답한 1 개 의원의 위탁검사 담당자는 간호조무사였다.

위탁검사목록 장부관리에 응답한 의원은 총 137 개 의원이었고 5 개 의원은 설문에 응하지 않았다. 응답한 137 개 의원 중 위탁 시 위탁검사 담당자가 위탁검사목록 장부를 확인을 하는 의원은 102 개(74.4\%) 의원이었고 담당자가 위탁검사목록 장부를 확인하지 않는 의원은 35 개 $(25.5 \%)$ 의원이었다. 위탁검사 담당자가 위탁검 사목록 장부를 확인하지 않는 35 개 의원 중 위탁검사 담당자의 직 급은 각각 간호사(27개), 간호조무사(8개)였다. 위탁검사 담당자 가 위탁검사 업무를 처음 시작할 때 채혈, 검체 용기, 보관방법 및 위탁방법에 대한 교육을 위탁검사 담당자에게 시행한 사람은 수탁 검사기관의 직원, 전임자, 관련 책자를 공부하거나 담당 의사가 직 접 교육한 순으로 조사되었다. 전임자와 수탁직원 두 사람이 위탁 검사 담당자에게 교육을 시행한 의원이 3 개 의원, 전임자에게 교 육을 받거나 책자를 통하여 공부한 의원이 1 개 의원, 수탁직원에 게 교육을 받거나 책자를 통하여 공부한 의원이 1 개 의원이었다. 즉 수탁검사기관의 직원 또는 전임자가 위탁검사 담당자가 위탁업무 시작 시 위탁검사 업무에 대해 교육을 시행한 의원이 $88.4 \%$ 였다.

직원안전에 관한 설문은 142 개 모든 의원에서 "채혈에 사용된 알코올 솜 등의 감염성 폐기물은 보관용기에 버려지고 있다"고 응 답하였고, "주사침(바늘) 등 손상성 폐기물도 전용용기에 버려지 고 있다"고 응답하였다(Table 1).

2. 제주지역 의원급 의료기관 위탁검사 채혈방법 및 장비현황 위탁검사를 위한 검체, 특히 혈액의 채취자의 직급에 대한 복수 
Table 1. Status of laboratory samples from medical clinics in Jeju island before delivery to the referral laboratory centers (general content) ( $\mathrm{N}=142)$

\begin{tabular}{lr}
\hline \multicolumn{1}{c}{ Questionnaire results } & No. (\%) \\
\hline Workers in charge of laboratory sample storage, handling & $78(54.9)$ \\
Registered nurse & $28(19.7)$ \\
Medical laboratory technologist & $27(19.0)$ \\
Licensed practical nurse & $1(0.7)$ \\
Radiological technologist & $8(5.6)$ \\
No dedicated person or workers from multiple healthcare job titles & $141(99.3)$ \\
Compliance of sample management guideline & $58(40.8)$ \\
Guidelines present/good compliance with guidelines & $31(21.8)$ \\
Guidelines present/bad compliance with guidelines & $51(35.9)$ \\
No guidelines/good sample management & $1(0.7)$ \\
No guidelines/bad sample management & \\
Who did instruct about the management of samples before the start of sample handling for the laboratory & \\
sample storage and delivery? & $62(43.7)$ \\
Delivery worker from referral laboratory & $60(42.2)$ \\
Predecessor & $7(4.9)$ \\
Study directly with related books & $5(3.5)$ \\
Doctor & $142(100.0)$ \\
Infectious waste is being thrown away in medical waste disposal containers. & $142(100.0)$ \\
Damaging waste is being thrown away in sharps containers.
\end{tabular}

응답 가능한 설문에서 간호사만 채혈, 간호조무사만 채혈, 임상병 리사만 채혈한다고 응답한 의원 순으로 조사되었으며, 간호사와 간호조무사의 두 직급이 채혈, 간호사와 임상병리사의 두 직급이 채혈, 간호사와 의사의 두 직급이 채혈, 간호사, 임상병리사, 간호 조무사의 세 직급이 채혈하는 순으로 복수응답하였다. 즉 위탁검 사를 위한 검체, 특히 혈액의 채취자의 직급은 복수응답한 의원을 포함해서 간호사 93 개(51.3\%), 간호조무사 53개(29.2\%), 임상병 리사 33 개( $18.2 \%)$, 의사 2 개(0.1\%) 의원의 순이었다.

간호사가 채혈한다고 응답한 93 개 의원 중 간호사가 위탁업무 를 담당한다고 응답한 기관은 83 개(89.2\%) 의원이고 임상병리사 가 채혈한다고 응답한 33 개 의원에서 임상병리사가 위탁업무를 담당한다고 응답한 의원은 30 개(90.9\%) 의원이고 간호조무사가 채혈한다고 응답한 53 개 의원에서 간호조무사가 위탁업무를 담당 한다고 응답한 의원은 32 개( $60.3 \%)$ 의원이었다.

검체 채취 전 환자 확인은 “환자분의 성함이 어떻게 됩니까" 등 개방적인 질문을 한다고 응답한 의원은 83 개 의원으로 $58.8 \%$ 이 었고, "환자분의 성함이 000 님 맞지요?" 등 폐쇄적인 질문을 한 다고 응답한 의원은 54 개 의원으로 $38.2 \%$ 이었고, "채혈 처방 후 검체 채취가 바로 이루어져 환자 확인에 크게 신경 쓰지 않는다"
고 응답한 의원은 4 개 의원으로 $2.8 \%$ 이었다. 채혈 시 환자가 앉 게 되는 의자는 “등받이가 있고 바퀴가 없는 의자이다"라고 응답 한 의원은 94 개 의원으로 $66.6 \%$, "등받이가 있고 바퀴가 있는 의 자이다"라고 응답한 의원은 18 개 의원으로 $12.7 \%$, "등받이가 없고 바퀴가 없는 의자이다"라고 응답한 의원은 20 개 의원으로 $14.1 \%$, “등받이가 없고 바퀴가 있는 의자이다"라고 응답한 의원 은 9 개 의원으로 $6.3 \%$ 였다.

검체 용기에 환자의 인적 사항을 기록하는 질문 중 "검체 채취 전 환자의 접수번호, 이름, 나이, 성별, 채취일 등을 기록한다"라고 응답한 의원은 126 개 의원으로 $88.7 \%$ 이었고, "검체 채취 후 환자 의 인적 사항, 채취일 등을 기록한다"라고 응답한 의원은 16 개 의 원으로 $11.2 \%$ 였다. 채혈 시 지혈대를 이용한 압박시간에 대한 질 문에서 1 분 이내로 압박한다는 의원이 108 개 의원으로 $76.0 \%$ 였 다. 2 분 이상 압박한다는 의원이 34 개 의원으로 총 $23.9 \%$ 였다.

채혈 시 알코올 소독시간에 대한 질문에 알코올 소독 후 바로 채 혈한다는 응답한 의원은 62 개 의원으로 $43.6 \%$ 였 10 초 이후에 채 혈한다는 응답한 의원은 80 개 의원으로 $56.3 \%$ 였다. 진공채혈 또 는 주사기를 이용하여 채혈할 때 채혈 용기의 채혈 순서에 대해 응 답한 의원은 총 138 개 의원이었다. 채혈 용기의 채혈 순서에서 여 
러 개의 채혈 용기가 필요할 때 "채혈 용기의 순서를 잘 알고 있으 며 이를 잘 지킨다"고 응답한 의원은 93 개 의원으로 $67.3 \%$ 였고, "채혈 용기 순서를 잘 알기는 하나 순서를 잘 지키지 못할 때가 있 다"고 응답한 의원이 39 개 의원으로 $28.2 \%$, “채혈 용기 순서를 모르고 있었다"고 응답한 의원이 6 개 의원으로 $4.3 \%$ 였다.

혈당검사용 검체 용기 종류에 대한 복수 선택에 응답한 의원 은 138 개 의원이었다. 이 중 sodium fluoride (NaF)만 사용한 다고 응답한 의원이 45 개 의원으로 가장 많았으며, 혈청분리튜 브(serum separation tube)를 사용한다고 응답한 의원, plain tube를 사용한다고 응답한 의원, $\mathrm{NaF}$ 와 혈청분리튜브를 사용한 다고 응답한 의원, plain tube와 ethylenediaminetetraacetic acid (EDTA) tube를 사용한다고 응답한 의원, 혈청분리튜브와 EDTA tube를 사용한다고 응답한 의원, NaF, plain tube, EDTA tube를 사용한다고 응답한 의원 순으로 조사되었으며 기타 튜브 를 사용한다고 응답한 의원 3 개 의원이었다.

설문지에 응답한 142 개 의원 중 141 개 의원에서 원심분리기 여 부에 응답하였고, 이 중 원심분리기를 보유하지 않은 의원은 86 개 의원으로 $61.0 \%$ 였다. "위탁검사지침이 있으며 잘 지키고 있다" 고 응답한 58 개 의원 중 응답하지 않은 1 개 의원을 제외한 57 개 의원 중 18 개(31.6\%) 의원이 원심분리기를 보유하지 않았고, "위 탁검사지침이 있으나 잘 지키고 있지 않다"고 응답한 31 개 의원 중 29개(93.5\%) 의원에서, "위탁검사지침이 없으나 검체 위탁은 잘 진행되고 있다”고 응답한 51 개 의원 중 37 개( $72.5 \%)$ 의원에서 원심분리기를 보유하고 있지 않았다. 원심분리기를 보유한 55 개 의원 중 채혈 후 혈청 검체를 위탁하기 전에 원심분리하는 시점은 채혈 후 1 시간 이내에 원심분리하는 의원, 2 시간 이내에 원심분리 하는 의원, 검체의 위탁 직전에 원심분리하는 의원, 원심분리를 하 지 않고 검체를 위탁하는 의원 순으로 조사되었다.

원심분리기를 보유한 55 개 의원 중 간호사가 위탁검사 담당자 인 의원이 19 개 의원이었고, 이 중 위탁 검체를 채혈 후 2 시간 이 내에 원심분리하는 의원이 17 개 의원, 간호조무사가 위탁검사 담 당자인 의원이 6 개 의원이었고, 이 중 위탁검사를 채혈 후 2 시 간 이내에 원심분리하는 의원이 5 개 의원, 임상병리사가 위탁검 사 담당자인 의원이 26 개 의원이며, 이 중 위탁검사를 채혈 후 2 시간 이내에 원심분리하는 의원이 23 개 의원이었다. 원심분리기 를 보유한 55 개 의원 중 원심분리기의 점검대장이 따로 있으며 관 리요령에 따라 주기적으로 점검, 기록하는 의원이 28 개 의원으로 $50.9 \%$, 원심분리기의 점검대장은 따로 없지만 주기적으로 원심 분리기의 상태를 점검하는 의원이 8 개 의원으로 $14.5 \%$, 원심분리 기의 관리는 따로 하지 않지만 검체의 혈청분리 여부를 보고 원심 분리 상태를 유추하는 의원이 19 개 의원으로 $34.5 \%$ 였다.

냉장보관 상태에 관한 설문에는 "위탁 검체 전용 냉장고가 있으
며 위탁 검체 외 의료용품은 함께 보관하지 않는다"고 응답한 의 원은 30 개 의원으로 $21.2 \%$, "위탁 검체 전용 냉장고가 있으나 위 탁 검체와 함께 기타 의료용품도 함께 보관한다"고 응답한 의원은 92 개 의원으로 $65.2 \%$, "위탁 검체를 보관하는 냉장고에 음료수,

Table 2. Status of laboratory samples from medical clinics in Jeju island before delivery to the referral laboratory centers (blood collection methods and equipment)

\begin{tabular}{|c|c|}
\hline Questionnaire results & No. (\%) \\
\hline \multicolumn{2}{|l|}{ Blood collector } \\
\hline RN & $60 / 141(42.6)$ \\
\hline LPN & $25 / 141(17.7)$ \\
\hline MLT & $22 / 141(15.6)$ \\
\hline RN/LPN & $22 / 141(15.6)$ \\
\hline $\mathrm{RN} / \mathrm{MLT}$ & $5 / 141(3.5)$ \\
\hline RN/doctor & 2/141 (1.4) \\
\hline RN/LPN/MLT & $4 / 141(2.8)$ \\
\hline \multicolumn{2}{|l|}{ Centrifugation time } \\
\hline$<1 \mathrm{hr}$ after sampling & $42 / 55(76.3)$ \\
\hline$<2 \mathrm{hr}$ after sampling & $5 / 55(9.0)$ \\
\hline Before sample delivery & $4 / 55(7.2)$ \\
\hline Delivery without centrifuge & $4 / 55(7.2)$ \\
\hline \multicolumn{2}{|l|}{ Centrifugation maintenance } \\
\hline Regular maintenance with sheet & $28 / 55(50.9)$ \\
\hline Regular maintenance without sheet & $8 / 55(14.5)$ \\
\hline Inference from serum separation & $19 / 55(34.5)$ \\
\hline \multicolumn{2}{|l|}{ Storage in refrigerator } \\
\hline Exclusive use for laboratory samples & $30 / 141(21.2)$ \\
\hline Storage with medical goods & $92 / 141(65.2)$ \\
\hline Storage with edible foods & $10 / 141(7.0)$ \\
\hline No storage in refrigerator & $9 / 141(6.3)$ \\
\hline \multicolumn{2}{|l|}{ Pickup time of laboratory samples } \\
\hline Daily pickup of laboratory samples & $124 / 142(87.3)$ \\
\hline Pickup time between before noon & $11 / 124(8.9)$ \\
\hline Pickup time between 1-3 PM & $57 / 124(46.0)$ \\
\hline Pickup time between 3-6 PM & $56 / 124(45.2)$ \\
\hline \multicolumn{2}{|l|}{ Pickup cycle of laboratory samples } \\
\hline 2 times/day & $7 / 142(4.9)$ \\
\hline 3 times/wk & $9 / 142(6.3)$ \\
\hline 2 times/wk & $1 / 142(0.7)$ \\
\hline 1 time/wk & $1 / 142(0.7)$ \\
\hline
\end{tabular}

(Continued on next page) 
Table 2. Continued

\begin{tabular}{lc}
\hline \multicolumn{1}{c}{ Questionnaire results } & No. (\%) \\
\hline Sample tubes for serum glucose test & \\
NaF only & $45 / 138(32.6)$ \\
SST only & $64 / 138(46.3)$ \\
Plain tube only & $5 / 138(3.6)$ \\
NaF+SST & $10 / 138(7.2)$ \\
Plain+EDTA & $6 / 138(4.3)$ \\
SST+EDTA & $3 / 138(2.2)$ \\
NaF+plain+EDTA & $2 / 138(1.4)$ \\
Others & $3 / 138(2.2)$ \\
\hline
\end{tabular}

Abbreviations: RN, registered nurse; LPN, licensed practical nurse; MLT, medical laboratory technologist; NaF, sodium fluoride; SST, serum separation tube; EDTA, ethylenediaminetetraacetic acid.

음식물 등도 보관된다"고 응답한 의원은 10 개 의원으로 $7.0 \%$ 였 다. "위탁 검체는 냉장보관하지 않는다"고 응답한 의원은 9 개 의 원으로 $6.3 \%$ 이었다. 냉장고 내부에 온도계가 비치되어 있어 온도 점검이 이루어진다고 응답한 의원은 99 개(70.7\%) 의원이었고 냉 장고 외부에 자동온도계를 통한 온도 점검이 이루어진다고 응답한 의원은 30 개(21.4\%) 의원이었다. 냉장고의 온도 점검이 이루어진 다고 응답한 129 개의 의원 중 매일 온도 점검이 이루어진다고 응 답한 의원은 62 개(48.0\%) 의원, 주마다 온도점검이 이루어진다고 응답한 의원은 67 개(51.9\%) 의원이었다. 온도 점검을 하지 않는 다고 응답한 의원은 11 개( $7.8 \%)$ 의원이었다.

위탁 검체의 수거는 매일 1 회 수거한다고 응답한 의원이 가장 많았으며, 매일 2회 수거, 주 3회 수거, 주 2회와 주 1회 수거된다 고 응답한 의원 순으로 응답하였다. 매일 수거된다고 응답한 124 개 의원 중 9-12시 사이에 수거된다고 응답한 의원은 11 개 의원, 13-15시 사이에 수거된다고 응답한 의원은 57개 의원, $15-18$ 시 사이에 수거된다고 응답한 의원은 56 개 의원이었다.

일반위탁검사(특수검사 제외)의 결과 보고시간에 관한 설문에 는 142 개 의원에서 위탁 검체에 대하여 특수검사를 제외하고 일 반검사의 결과 보고시간이 당일인 의원은 4 의원, 익일인 의원은 126 의원, 3 일인 의원은 12 의원이었다. 위탁검사 결과 보고시간이 적절하다고 응답한 의원이 126 개 의원, 적절하나 더 신속히 보고 되면 좋겠다고 응답한 의원이 15 개 의원, 적절하지 않다고 응답한 의원이 1 개 의원이었다(Table 2).

\section{고찰}

환자에서 채취한 검체를 이용하여 질병의 진단, 경과 관찰, 치료
및 예후를 판정하는 검체검사는 임상에서 매우 중요한 분야이다 $[8,9]$. 최근 정보기술(information technology)의 발달과 장비의 첨단화에 따라 환자의 진료에 차지하는 검체검사의 비율은 점진적 으로 증가하고 있다[10,11]. 이러한 검체검사는 많은 인력과 최신 장비가 필요하기 때문에 병 의원의 규모에 따라 일부 혹은 대부분 의 검체검사를 전문 수탁검사 의료기관에게 의뢰하여 실시하고 있 다[3]. 제주지역인 경우 전문 수탁검사 의료기관은 1 곳 뿐이며, 대 부분의 수탁 검체는 제주 이외 지역에 위치한 대형 전문 수탁검사 의료기관에 보내져 검체검사가 이루어지고 있다.

혈액을 포함한 임상 검체는 보존기간, 적정온도, 감염위험 등 신 중히 관리되어야 하며, 운반과정 중 임상 검체의 손실, 상태유지, 온도유지 등 검사결과에 영향을 일으키는 요인들을 고려해야 한 다. 연구에 의하면 채혈량이 부족한 시험관에서 용혈이 더 빈번하 고, 냉매가 들어 있는 운송상자 내 검체들의 결과 변이가 더 적었 으며, 우리나라에서 검체의 평균 운송시간은 11.3 시간이고 원심 분리가 안된 냉장 운송 검체의 혈중 칼륨 농도가 더 높은 것으로 나타나므로 검체는 운송 전 반드시 원심분리하여야 한다고 보고하 였다[12].

본 연구는 제주도 의원급 의료기관에서의 검체의 전 처리, 종사 하는 인력, 장비, 보관방법 등 수탁검사 의료기관으로 위탁 전 과 정에서 위탁 검체 관리실태를 설문을 통하여 조사한 결과, 위탁검 사 업무에 대한 전반적인 면에서 부족한 점이 많았다. 특히 채혈과 정, 원심분리, 검체 보관, 기기점검, 교육 부분에서 미비한 점이 많 았다고 판단된다.

제주지역의 특수성을 고려할 때 위탁검사에서 발생할 수 있는 문제점을 인식하기 위하여 수탁을 위한 임상 검체에 대해서도 정 기적인 인증과 지속적인 교육이 필요하다고 생각된다. 이를 통한 주기적인 지도 감독으로 의원급 의료기관에 내원하여 진료를 받는 환자들의 정확한 임상결과로 인한 적절한 진료를 위해 노력해야 한다고 생각된다.

\section{감사의 글}

이 논문은 대한임상검사정도관리협회 2018년 학술연구비 지원 에 의해 이루어진 것이다(2018-02).

\section{ORCID}

Moo-Sang Chong https://orcid.org/0000-0001-9582-6005 Kyutaeg Lee https://orcid.org/0000-0003-0729-688X 


\section{REFERENCES}

1. Huisman W, Horvath AR, Burnett D, Blaton V, Czikkely R, Jansen RT, et al. Accreditation of medical laboratories in the European Union. Clin Chem Lab Med 2007;45:268-75.

2. Plebani M. Errors in clinical laboratories or errors in laboratory medicine? Clin Chem Lab Med 2006;44:750-9.

3. Bae SY, Kwon JA, Kim JS, Yoon SY, Lee CK, Lee KN, et al. Survey results of medical insurance reimbursement system for independent medical laboratories in Korea. Korean J Lab Med 2007;27:143-50.

4. Berg B, Estborn B, Tryding N. Stability of serum and blood constituents during mail transport. Scand J Clin Lab Invest 1981;41:425-30.

5. Jensen EA, Stahl M, Brandslund I, Grinsted P. Stability of heparin blood samples during transport based on defined pre-analytical quality goals. Clin Chem Lab Med 2008;46:225-34.

6. Sinclair D, Briston P, Young R, Pepin N. Seasonal pseudohyperkalaemia. J Clin Pathol 2003;56:385-8.

7. Lee SG, Kwon A, Park S, Seo S, Kim YJ, Shim H, et al. Validation of temperature preservation in specimen transportation systems. Lab Med Online 2020;10:116-24.

8. Henry JB, Kurec AS. The clinical laboratory: organization, purposes, and practice. In: Henry JB, ed. Clinical diagnosis and management by laboratory methods. 20th ed. Philadelphia (PA): WB Saunders, 2001:3-7.

9. Travers ED, McClatchey KD. Basic laboratory management. In: MaClatchey KD, ed. Clinical laboratory medicine. 2nd ed. Philadelphia (PA): Lippincott Williams \& Wilkins, 2002:3-4.

10. Suh IB, Ma KR, Lee SM, Kwon JA, Bae SY, Yoon SY, et al. Management of clinical laboratory staffs in Korea (II). J Lab Med Qual Assur 2002;24:237-42.

11. Mori M. Activity of clinical laboratory physicians in national health insurance. Rinsho Byori 2005;53:1030-5.

12. Lim HS, Lee YK, Min WK. Effects of long distance transportation of specimens on test results. Lab Med Online 2011;1:72-80. 
Appendix 1. Questionnaire for the referral sample management of clinics in Jeju

귀 병(의)원의 발전을 기원합니다.

대한임상검사정도관리학회에서 제주한라대학교 임상병리과 정무상 교수, 제주한라병원 진단검사의 학과 이규택 과장이 함께 “제주도 내 일차의원에서 검체 검사의 위탁 검체 관리 실태 파악 및 개선 방안 모색»이라는 주제로 연구를 진행하고 있습니다.

정확하고 빠른 결과는 올바른 검체 의뢰가 선행되어야 함을 모두 인지하는 바입니다. 연구의 일환 으로 귀 병(의)원에서 위탁검사(수탁기관에 검사의뢰)의 구조, 검체 위탁 전 과정, 검체 결과의 처리 절차 및 바라는 점에 대한 파악하여 더 나은 의뢰결과로 인한 제주도민의 건강에 도움이 되고자 합 니다.

원장님의 의견은 제주도 일차병(의)원들의 위탁검사의 발전에 큰 도움이 되는 중요한 자료가 될 것 이므로 솔직하게 응답해 주시기 바랍니다.

설문조사의 내용은 비밀이 절대 보장되며 연구목적 이외에 다른 용도로 이용되지 않을 것을 약속드 립니다. 또한, 병(의)원명, 위탁 업체명, 담당자 등을 모두 무기명으로 조사한다는 점을 말씀드립니다.

감사합니다.

연락처 :

제주한라대학교 임상병리과 정무상 교수

전화번호: 064-741-6732, 이메일 : chong@chu.ac.kr

제주한라병원 진단검사의학과 이규택 과장(전문의)

전화번호: 064-740-5255, 이메일: kyutaeg@daum.net

※ 본 설문지를 작성 후 봉투에 밀봉하여 무기명으로 위탁기관 업체에 전달해 주시기 바랍니다. 
기본 정보

귀 병(의)원 원내에서 실행하고 있는 검사종목을 모두 표시해 주십시오.

$\square$ 일반화학검사(간수치, 콜레스테롤, 신장수치 등)

$\square$ 일반혈액검사(빈혈, 백혈구, 혈소판 등)

$\square$ 일반면역검사(B형 간염, C형 간염 등)

$\square$ 요검사 (urine strip)

$\square$ 간이혈당검사 (glucometer)

$\square$ 간이검사(kit를 이용한 hepatitis B virus, influenza 등)

\section{설문지 문항}

1. 귀원의 위탁검사 담당자는 누구입니까?
(1) 간호사
(2) 간호조무사
(3) 임상병리사
(4) 방사선사
(5) 물리치료사
(6) 사무직원
(7) 담당자의 순환변경

2. 귀원의 위탁검사에 대한 지침(검사 가이드라인)이 있습니까?
(1) 위탁검사 지침이 있으며, 잘 지키고 있다.
(2) 위탁검사 지침이 있으나, 잘 지키고 있지 않다.
(3) 위탁검사 지침이 없으나, 검체 위탁은 잘 진행되고 있다.
(4) 위탁검사 지침이 없으며, 잘 지키고 있지 않다.

3. 위탁검사를 위한 검체(혈액)의 채취는 누가합니까? (복수 응답 가능)
(1) 임상병리사
(2) 간호사
(3) 간호조무사
(4) 사원
(5) 의사

4. 위탁검사 목록에 대한 검체 위탁검사 장부를 작성합니까?

(1) 위탁검사 장부를 수탁기관 직원이 작성하며, 위탁검사 담당자가 확인한다.

(2) 위탁검사 장부를 수탁기관 직원이 작성하나, 위탁검사 담당자가 확인을 안한다.

(3) 위탁검사 장부를 수탁기관 직원이 작성하지 않으나, 위탁검사 담당자가 확인한다.

(4) 위탁검사 장부도 확인도 하지 않는다. 


\section{설문지 문항}

5. 위탁검사 담당자가 위탁검사 업무를 시작할 때 검체 용기, 보관방법 및 위탁방법에 대한 교육을 받았습니까?
(1) 예, 원장님께서 직접 교육해 주셨습니다.
(2) 예, 수탁기관의 직원이 교육해 주셨습니다.
(3) 예, 전임자 또는 선임자가 직접 교육해 주셨습니다.
(4) 예, 관련 책자를 보고 직접 공부하였습니다.
(5) 아니오, 교육을 받지 않았습니다.

6. 채혈 공간이 따로 마련되어 있습니까?

(1) 예, 검체 용기 및 채혈기기가 준비되어 있는 공간에서 채혈합니다.

(2) 예, 검체 용기 및 채혈기기가 채혈 공간 외에 준비되어 있으나 채혈 위한 단독 공간이 있습니다.

(3) 예, 지정된 공간은 없지만 항상 동일 공간에서 이루어집니다.

(4) 특정 공간이 없어 매번 채혈 장소는 변경됩니다.

7. 채혈 시 지혈대(tourniquet)를 평균 얼마 동안 묶고 채혈을 합니까?
(1) 30 초 이내
(2) 1 분 이내
(3) 2 분 이내
(4) 3 분 이내

8. 채혈 시 알코올(alcohol) 소독을 한 다음 얼마나 지나서 채혈을 합니까?

(1) 바로 채혈한다.

(2) 10 초 후에 채혈한다.

(3) 30 초 후에 채혈한다.

(4) 1 분 후에 채혈한다.

9. 위탁검사를 수탁기관 직원이 수거하기 전, 혈청 검체는 원심분리 후 혈청분리하여 위탁합니까?

(1) 예, 채혈 후 1 시간 이내에 원심분리를 합니다.

(2) 예, 채혈 후 2시간 이내에 원심분리를 합니다.

(3) 예, 수탁기관 직원이 수거하기 직전에 원심분리를 합니다.

(4) 원심분리하지 않고 위탁합니다.

10. 원심분리기는 주기적으로 점검합니까?

(1) 원심분리기 점검대장이 따로 있으며, 관리 요령에 따라 주기적으로 점검, 기록한다.

(2) 원심분리기 점검대장은 따로 없지만, 주기적으로 원심분리의 상태를 점검한다.

(3) 원심분리기 관리는 따로 하지 않으나, 검체의 혈청분리 여부를 보고 원심분리 상태를 유추하여 판단한다.

(4) 원심분리기가 없다. 


\section{설문지 문항}

11. 혈청분리 위한 원심분리기의 사용시간 및 원심분리 속도는 얼마입니까?
$\square 1,000 \mathrm{rpm}$
$\square 3$ 분
$\square 1,500 \mathrm{rpm}$
$\square 5$ 분
$\square 2,000 \mathrm{rpm}$
$\square 10$ 분
$\square 2,500 \mathrm{rpm}$
$\square 15$ 분
$\square 3,500 \mathrm{rpm}$ 이상
$\square 20$ 분 이상

12. 요검사 중 요침사검사를 시행한다면, 요침사검사를 위한 원심분리기의 사용시간 및 원심분리 속도는 얼마입니까?
$\square 1,000 \mathrm{rpm}$
$\square 3$ 분
$\square 1,500 \mathrm{rpm}$
$\square 5$ 분
$\square 2,000 \mathrm{rpm}$
$\square 10$ 분
$\square 2,500 \mathrm{rpm}$
$\square 15$ 분
$\square 3,500 \mathrm{rpm}$ 이상
20 분 이상

13. 위탁검사 전 검체를 보관하는 냉장고가 있습니까?

(1) 예, 위탁 검체 전용 냉장고가 있으며, 위탁 검체 외 의료용품은 함께 보관하지 않습니다.

(2) 예, 위탁 검체 전용 냉장고가 있으나, 위탁 검체 외 의료용품도 함께 보관하고 있습니다.

(3) 예, 위탁 검체 전용 냉장고가 있으나, 위탁 검체 외 음료수, 음식물 등도 함께 보관하고 있습니다.

(4) 예, 위탁 검체 전용 냉장고가 있으나, 특정 냉장고를 지정하고 있지 않습니다.

(5) 위탁 검체는 냉장고에 보관하지 않습니다.

14. 위탁검사 전용 냉장고는 주기적으로 점검하여 사용합니까?

(1) 예, 위탁 검체 전용 냉장고 안에 온도계가 비치되어 있어 매일 온도 체크를 합니다.

(2) 예, 위탁 검체 전용 냉장고 안에 온도계가 비치되어 있어 매주 온도 체크를 합니다.

(3) 예, 위탁 검체 전용 냉장고 외부에 자동온도계를 통하여 매일 온도 체크를 합니다.

(4) 예, 위탁 검체 전용 냉장고 외부에 자동온도계를 통하여 매주 온도 체크를 합니다.

(5) 위탁 검체는 냉장고에 보관하지 않습니다.

15. 검체 채취 전 환자는 어떻게 확인합니까?

(1) “환자 분의 성함이 어떻게 됩니까?” 등 개방적인 질문하여 확인한다.

(2) “환자분 성함이 $\mathrm{OOO}$ 님 맞지요?” 등 폐쇄적인 질문하여 확인한다.

(3) 원장님 처방 후 바로 검체 채취가 이루어지게 되어 환자 확인에 크게 신경쓰지 않아도 된다.

16. 환자가 앉는 채혈의자는 안전한 의자입니까?

(1) 환자가 앉는 채혈의자는 등받이가 있고 바퀴가 없는 의자이다.

(2) 환자가 앉는 채혈의자는 등받이가 있고 바퀴도 있는 의자이다.

(3) 환자가 앉는 채혈의자는 등받이가 없고 바퀴가 없는 의자이다.

(4) 환자가 앉는 채혈의자는 등받이가 없고 바퀴가 있는 의자이다. 


\section{설문지 문항}

17. 위탁검사로 혈당검사를 의뢰할 시, 검체 채취 용기는 무엇입니까? (복수 응답 가능)

(1) Sodium fluoride (NaF; 회색 뚜껑)

(2) Serum separator tube (SST; 노란색 뚜껑)

(3) Plain(빨간색 뚜껑)

(4) Ethylenediaminetetraacetic acid (EDTA; 보라색 뚜껑)

(5) Citrate(파란색 뚜껑)

(6) 기타

18. 요검사를 위한 소변 채취 시에 소변 채취법을 어떻게 설명합니까?

(1) “처음 나오는 소변은 버리고 중간뇨를 $10 \mathrm{~mL}$ 이상(소변컵의 반 정도) 받아주세요”라고 설명합니다

(2) “중간뇨를 $10 \mathrm{~mL}$ 이상 (소변컵의 반 정도) 받아주세요” 라고 설명합니다.

(3) “소변컵의 반 정도 받아주세요”라고 설명합니다.

(4) 특별한 설명은 하지 않는다.

※ 요검사는 아침 첫 뇨가 권장되며, 채취 1-2시간 내에 검사되어야 한다. 부득이하게 검사가 지연되는 경우 즉시 냉장하여야 하고, 검자 전에 실온 상태로 만든 후 검사한다.

19. 검체 용기에 환자의 인적 사항을 어떻게 기록합니까? (바코드 또는 수기기록 내용)

(1) 검체 채취 전 환자의 접수번호, 이름, 나이, 성별, 채취일을 모두 기록한다.

(2) 검체 채취 전 환자의 접수번호, 이름, 나이, 성별, 채취일의 일부만 기록한다.

(3) 검체 채취 후 환자의 접수번호, 이름, 나이, 성별, 채취일을 모두 기록한다.

(4) 검체 채취 후 환자의 접수번호, 이름, 나이, 성별, 채취일의 일부만 기록한다.

20. 진공채혈 또는 주사기를 이용하여 채혈할 때 여러 개의 채혈 용기가 필요할 때 채혈 용기의 순서를 잘 지키고 있습니까?

(1) 채혈 용기 순서를 잘 알고 있으며 이를 잘 지킨다.

(2) 채혈 용기 순서를 잘 알기는 하나 순서를 잘 지키지 못 할 때가 있다.

(3) 채혈 용기 순서를 모르고 있었다.

※ 채혈 용기 순서는 다음과 같습니다.

Non-additive tube (glass plain tube without a clot activator, red stopper) $\rightarrow$ coagulation tube (citrate tube, blue stopper) $\rightarrow$ SST/plain tube (serum tube with or without gel, red stopper) $\rightarrow$ EDTA tube (lavender stopper) $\rightarrow$ 그 외 oxalate/fluoride tube (gray stopper)

21. 채혈에 사용된 알코올 솜 등은 감염성 폐기물의 보관용기에 버려지고 있습니까?

(1) 예

(2) 아니오 


\section{설문지 문항}

22. 주사침(바늘)은 손상성 감염성 폐기물 전용 용기(플라스틱 용기)에 버려지고 있습니까?

(1) 예

(2) 아니오

23. 임상화학검사(혈당수치, 간수치, 콜레스테롤, 신장수치 등)을 위한 수탁 검체를 위탁하는 형태는?

(1) 전혈을 원심분리하여 상층(혈청)을 별도 용기에 분리하여 전달

(2) SST 튜브에 채혈한 검체를 원심 분리하여, 세포층과 혈청이 gel에 의해 분리된 상태로 전달

(3) 원심분리하지 않고 전혈 검체를 그대로 전달

(4) 임상화학검사를 위탁검사하지 않음

24. 소변검사를 위한 수탁 검체를 위탁하는 형태는?

(1) 소변을 전용 용기(뚜껑 있는 컵)에 채취하여, 냉장고에 보관 후 전달

(2) 소변을 전용 용기(뚜껑 있는 컵)에 채취하여, 실온에 보관 후 전달

(3) 소변을 다른 용기(튜브나 혈청분리관)에 옮긴 후, 냉장고에 보관 후 전달

(4) 소변을 다른 용기(튜브나 혈청분리관)에 옮긴 후, 실온에 보관 후 전달

(5) 요화학검사를 위탁검사하지 않음

25. 일반혈액검사(백혈구, 빈혈수치, 혈소판 등)을 위한 수탁 검체를 위탁하는 형태는?

(1) 전용 용기에 채취하여, 응고 여부를 확인하여 전달

(2) 전용 용기에 채취하여, 응고 여부를 확인하지 않고 전달

(3) 혈액검사를 위탁검사하지 않음

26. 위탁 검체 수거는 하루 몇 번 수거합니까?

(1) 매일 1 회

(2) 매일 2 회

(3) 주 1 회

(4) 주 2 회

(5) 주 3 회

27. 위탁 검체 수거는 언제 이루어집니까? (복수 응답 가능)

(1) 오전 9-12시

(2) 오후 $1-3$ 시

(3) 오후 3-6시

(4) 오후 6시 이후

28. 위탁기관의 검사결과는 적절한 시간에 보고된다고 생각합니까?

(1) 예, 적절한 시간에 보고됩니다.

(2) 예, 적절한 시간에 보고되나 더 신속히 보고되면 좋겠습니다.

(3) 종종 적절한 시간을 벗어나서 보고되는 경우가 있습니다.

(4) 자주 적절한 시간을 벗어나서 보고됩니다. 


\section{설문지 문항}

29. 위탁검진기관에 일반수탁검사(특수검사 제외)를 의뢰하고, 결과를 보고 받는 평균일수는?

(1) 당일

(2) 익일

(3) 3 일

(4) 4 일

(5) 5 일 이상

30. 임상적으로 응급 치료나 추가 진단을 요하는 환자결과의 경우 공식결과지를 받기 전에 위탁기관에게서 유·무선 등으로 결과를 통보받은 적이 있습니까?

(1) 예, 제주도 위탁검사 소장, 검체 수거 직원에게 연락받았습니다.

(2) 예, 검사를 직접 시행하는 위탁검사 직원(임상병리사)에게 연락받았습니다.

(3) 예, 검사를 직접 시행하는 위탁검사 진단검사의학과 또는 병리과 전문의에게 연락받았습니다.

(4) 아니오, 결과를 통보받은 적이 없습니다.

31. 위탁검사로 혈액형 검사 $(\mathrm{ABO}, \mathrm{Rh})$ 를 의뢰할 시, 검체 채취 용기는 무엇입니까?

(1) $\mathrm{NaF}$ (회색 뚜겅)

(2) $\operatorname{SST}($ 노란색 뚜껑)

(3) Plain(빨간색 뚜껑)

(4) $\operatorname{EDTA}($ 보라색 뚜껑)

(5) Citrate(파란색 뚜껑)

(6) $\operatorname{EDTA}($ 보라색 뚜껑) + plain(빨간색 뚜껑)

(7) $\operatorname{EDTA}($ 보라색 뚜껑) $+\mathrm{SST}$ (노란색 뚜껑)

(8) 기타

32. 현 위탁기관을 통하여 일차 진료를 담당하시는 동안 응급으로 당일에 환자 결과를 받아보시기 원하는 검사항목이 있습니까? 있으시다면 적어주시기 바랍니다.

(1)

(2)

(3)

(4)

(5)

33. 위탁기관에 바라는 점이 있으면 자유롭게 적어주시기 바랍니다.

※ 설문에 응답하여 주셔서 감사드립니다.

※ 소중한 의견은 제주도 일차병(의)원들의 위탁검사의 발전에 큰 도움이 될 것입니다. 